\title{
Broadband Seismic Station Deployment at Hadabat Al-Marhi, Halban, Saudia Arabia
}

A. Rodgers, J. P. Lewis, and A. Al-Amri

February 11, 2002

U.S. Department of Energy

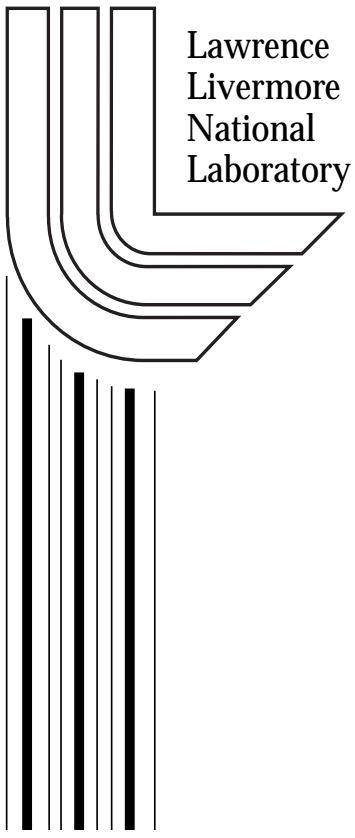




\section{DISCLAIMER}

This document was prepared as an account of work sponsored by an agency of the United States Government. Neither the United States Government nor the University of California nor any of their employees, makes any warranty, express or implied, or assumes any legal liability or responsibility for the accuracy, completeness, or usefulness of any information, apparatus, product, or process disclosed, or represents that its use would not infringe privately owned rights. Reference herein to any specific commercial product, process, or service by trade name, trademark, manufacturer, or otherwise, does not necessarily constitute or imply its endorsement, recommendation, or favoring by the United States Government or the University of California. The views and opinions of authors expressed herein do not necessarily state or reflect those of the United States Government or the University of California, and shall not be used for advertising or product endorsement purposes.

This work was performed under the auspices of the U. S. Department of Energy by the University of California, Lawrence Livermore National Laboratory under Contract No. W-7405-Eng-48.

This report has been reproduced directly from the best available copy.

Available electronically at http://www.doc.gov/bridge

Available for a processing fee to U.S. Department of Energy

And its contractors in paper from

U.S. Department of Energy

Office of Scientific and Technical Information

P.O. Box 62

Oak Ridge, TN 37831-0062

Telephone: (865) 576-8401

Facsimile: (865) 576-5728

E-mail: reports@adonis.osti.gov

Available for the sale to the public from

U.S. Department of Commerce

National Technical Information Service

5285 Port Royal Road

Springfield, VA 22161

Telephone: (800) 553-6847

Facsimile: (703) 605-6900

E-mail: orders@ntis.fedworld.gov

Online ordering: http://www.ntis.gov/ordering.htm

OR

Lawrence Livermore National Laboratory

Technical Information Department's Digital Library

http://www.llnl.gov/tid/Library.html 


\section{Broadband Seismic Station Deployment at Hadabat Al-Mahri, Halban Saudi Arabia}

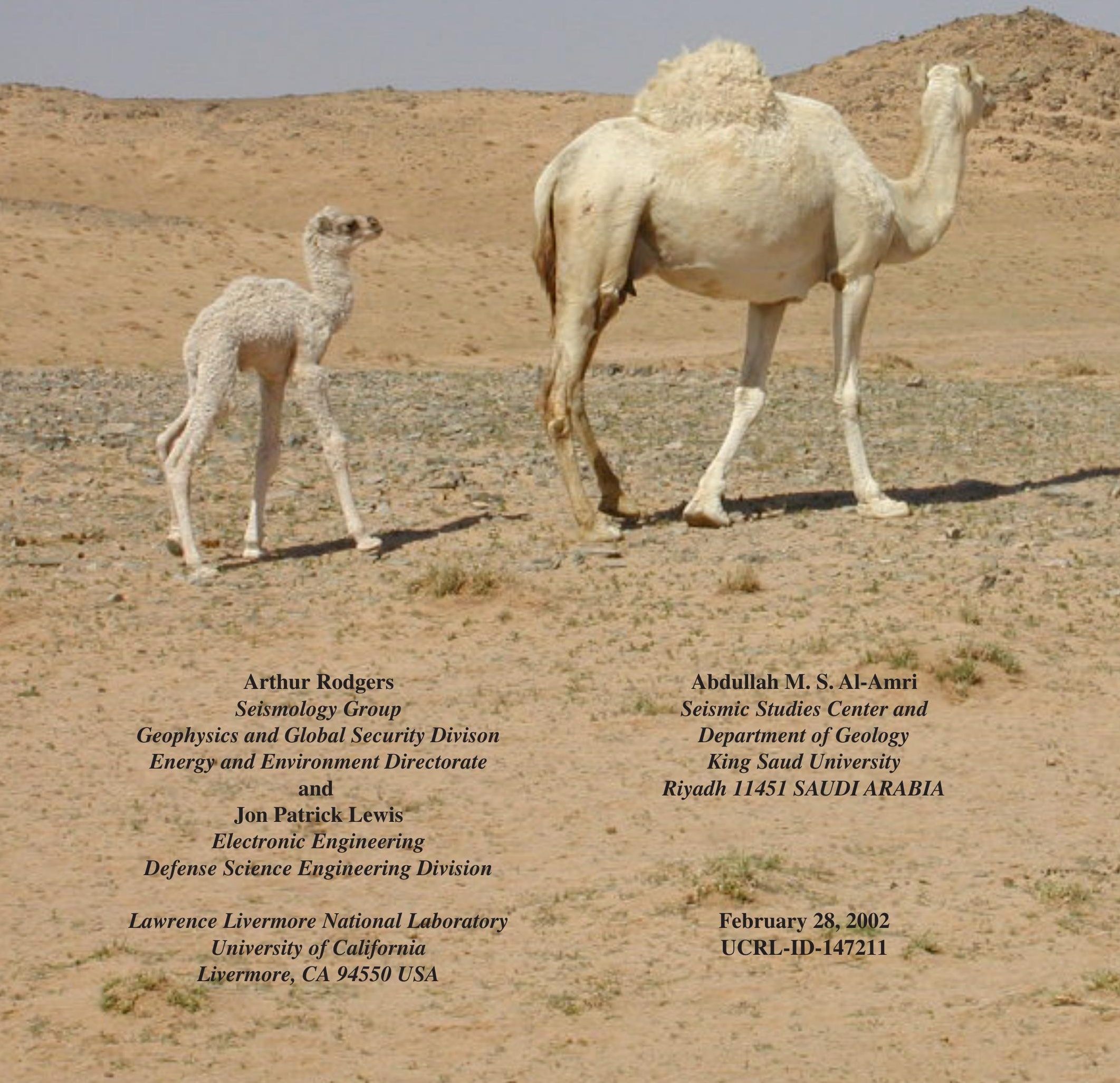




\begin{abstract}
A broadband three-component seismic station was deployed on the Arabian Shield near the town of Halban in central Saudi Arabia. This site is near the proposed site of a primary seismic array (PS38) of the International Monitoring System (IMS) of the Comprehensive Nuclear Test-Ban Treaty (CTBT). The purpose of this deployment was to collect calibration data for the primary array to be deployed in the future.
\end{abstract}

\title{
Introduction
}

The International Monitoring System (IMS) of the Comprehensive Nuclear Test-Ban Treaty Organization (CTBT0) will rely on seismic stations and arrays to monitor nuclear explosions. An IMS primary seismic array is being planned near the town of Halban on the Arabian Shield in central Saudi Arabia. Figure 1 shows a map of the Middle East with existing and planned IMS seismic stations.

A Department of Energy (DOE) Research Opportunity Announcement (ROA) project was funded to collect calibration data for explosion monitoring of the Arabian Peninsula. A major part of this project ("Ground Truth Event and Waveform Data Collection for Seismic Calibration of the Arabian Peninsula and Surrounding Regions - Project \#35) is to collect calibration data for the primary array near Halban, Saudi Arabia. During the week of January 21-27, 2002 Lawrence Livemore National Laboratory (LLNL) and King Saudi University (KSU) seismologists deployed an autonomous broadband seismic station near Halban. This deployment took advantage of the vault built for station HALM by the 1995-1997 University of California, San Diego (UCSD) Saudi Broadband Deployment (Vernon and Berger, 1998; also funded by DOE). Noise characteristics from the UCSD Deployment indicate that the HALM site was very quiet (Mellors, 1997; Al-Amri et al., 1999). Table 1 summarizes seismic station deployments near Halban. Directions to the site are included in the appendix. 


\section{Instrumentation}

The LLNL deployment features a Guralp CMG-3T three-component broadband seismometer (passband $0.008-50 \mathrm{~Hz}$ or $125-0.02 \mathrm{~s}$ ). Data are recorded by a Reftek 072A 24-bit digitizer on to a 1 Gigabyte SCSI field disk. Timing is determined every hour by GPS at the site. The system is powered by a 12-Volt (100 Ampere ) battery that is recharged by a solar panel. The sensor and digitizer are placed in a vault built for the 1995-1997 UCSD-Saudi Broadband Deployment (Vernon and Berger, 1999). Figure 2 shows the site after installation.

\section{IMS Array Site}

The IMS primary seismic station (PS38) is being planned near Halban (Table 1, Figure 3). In April 2001 the Prepatory Commission for the CTBTO and King Abdulaziz City of Science and Technology (KACST) performed a site survey at the KACST-proposed site. During the LLNL-KSU deployment, we learned that the KACST-proposed site is approximately $65 \mathrm{~km}$ away from our site. The KACST site is much closer to the highway and the town of Halban. There are many beduoin encampments closer to the highway and security may be an issue. The array site will require a $4 \mathrm{~km}$ by $4 \mathrm{~km}$ footprint to be enclosed by a fence. The Hadabat Al-Marhi site is more remote and less likely to be disturbed. Once the site of the array is chosen and secured with a fence, we would like to deploy a station at the exact IMS site. We will then be able to compare observations at both the Hadabat Al-Harhi and IMS array sites to estimate the transfer function between the two sites. 
Table 1. Summary of Seismic Station Deployments near Halban, central Saudi Arabia.

\begin{tabular}{|l|l|l|l|l|l|l|l|}
\hline Station Code & Institution & On Date & Off Date & Latitude & Longitude & Elevation & Sensor \\
\hline HALM & UCSD & $1995 / 327$ & $1997 / 060$ & 22.8454 & 44.3173 & $930 \mathrm{~m}$ & STS-2 \\
\hline HALB & LLNL/KSU & $2002 / 021$ & present & 22.8452 & 44.3173 & $930 \mathrm{~m}$ & Guralp-3T \\
\hline PS38 & KACST & $\begin{array}{l}\text { To be } \\
\text { determined }\end{array}$ & $\begin{array}{l}\text { To be } \\
\text { determined }\end{array}$ & 23.4349 & 44.4894 & $? ? ?$ & array \\
\hline
\end{tabular}

\section{Acknowledgements}

Rob Mellors and Frank Vernon kindly provided their field notes and maps to help locate the site. Don Rock prepared the equipment and loan documentation.

Ahmad Rabie Khalil (KSU) helped set-up the KSU computer system and read the field disks. AR and JPL thank the staff of the KSU Seismic Studies Center for their kind hospitality during our visit to Saudi Arabia. This work was performed under the auspices of the U. S. Department of Energy by the University of California, Lawrence Livermore National Laboratory under Contract No. W7405-Eng-48.

\section{References}

Al-Amri, A. M., R. Mellors and F. Vernon (1999). Broadband seismic noise charateristics of the Arabian Shield, The Arabian Journal for Science and Engineering, 24, 2A, 99-113.

Mellors, R. (1997). Preliminary noise survey and data report of Saudi Arabian data, Lawrence Livermore National Laboratory Informal Document, UCRL-ID-128949.

Vernon, F. and J. Berger (1998). Broadband seismic characterization of the Arabian Shield, Final Scientific Technical Report, Department of Energy Contract No. F 1962895-K-0015, $36 \mathrm{pp}$. 


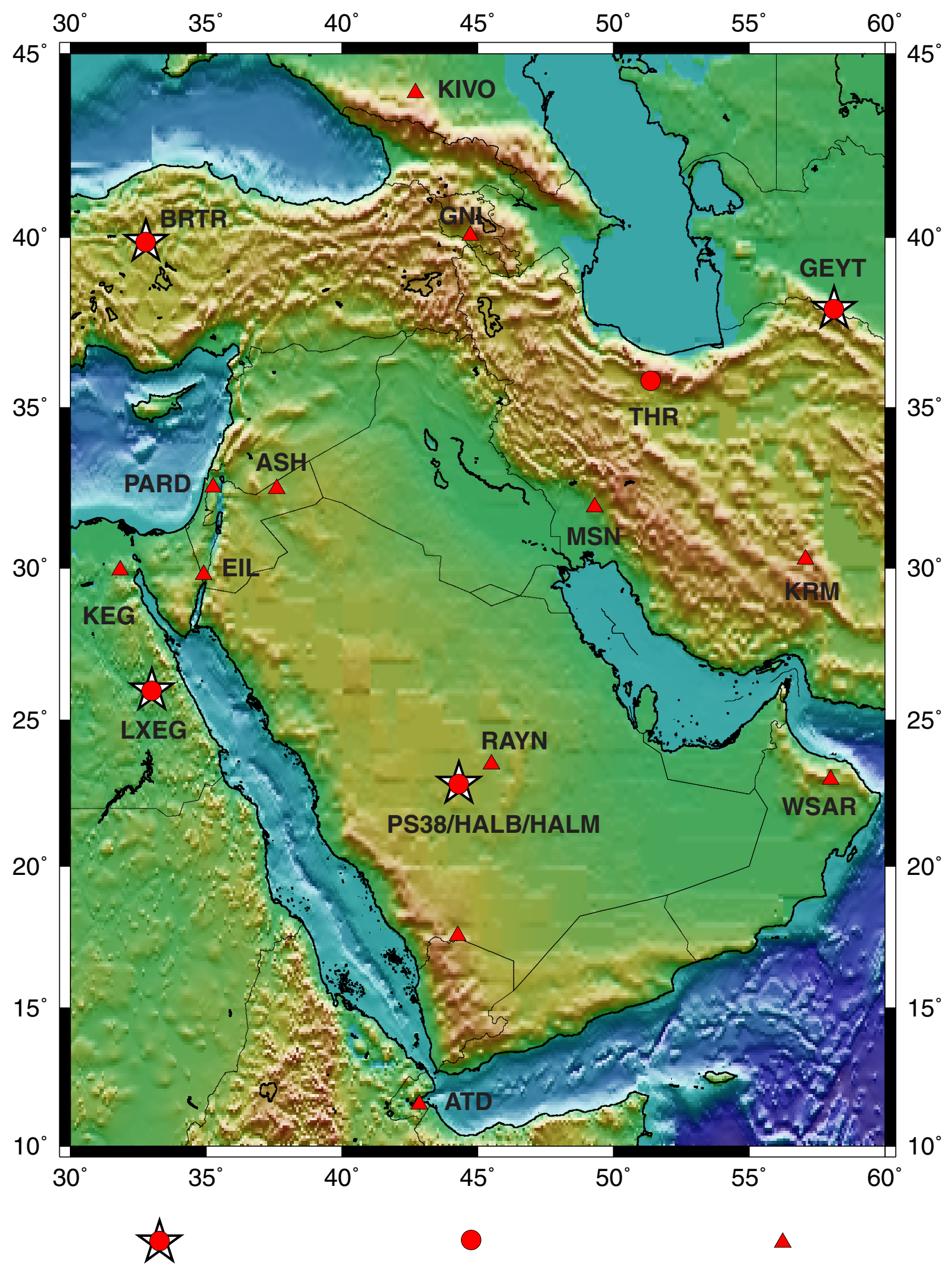

Primary Array

Primary Single

Auxiliary

Figure 1. Map of International Monitoring System stations in the Middle East. 

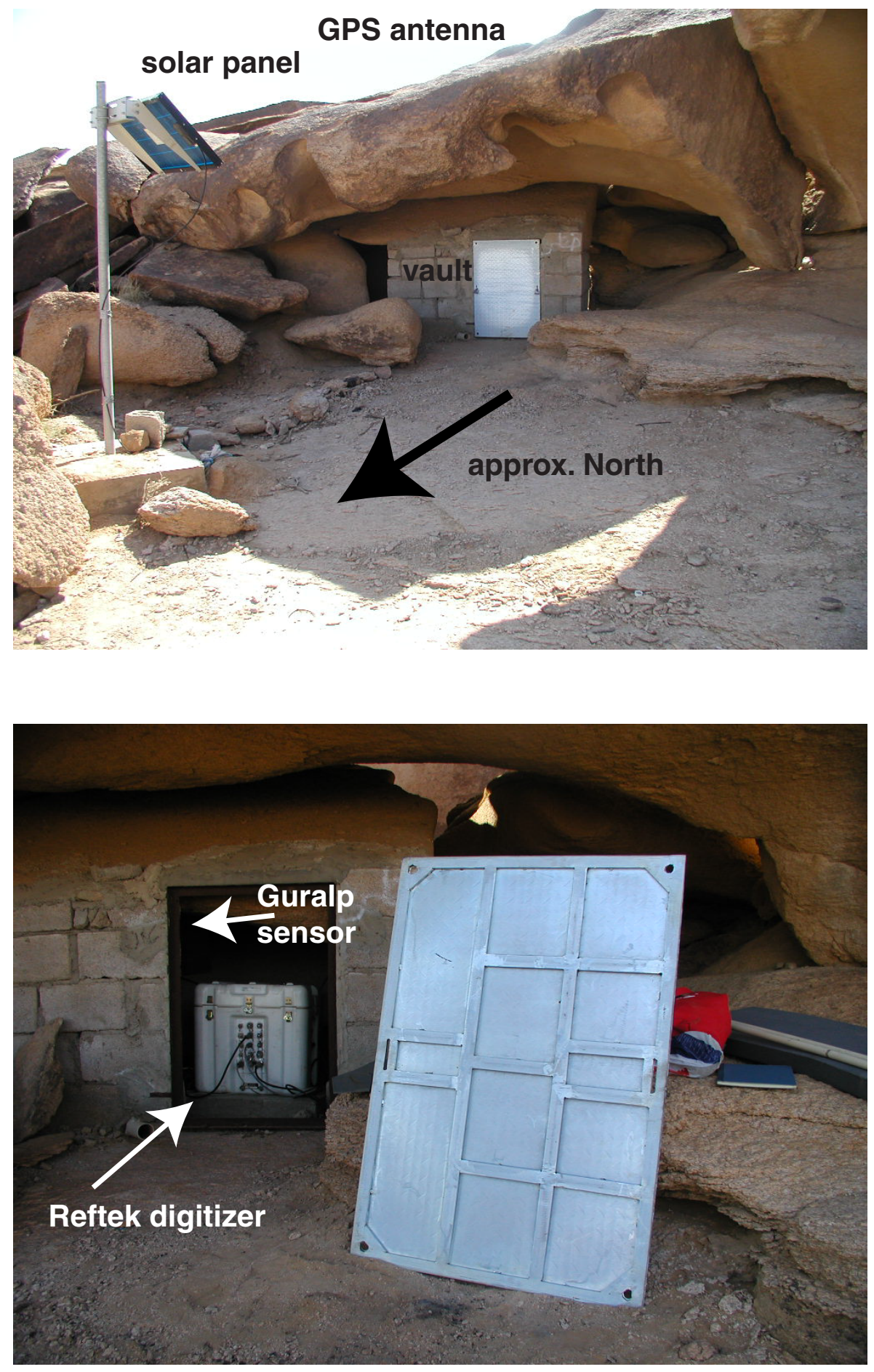

Figure 2. HALB station site. (a) Overview of site showing the vault, solar panel and mast. The GPS antenna is located on the overhanging rock above the vault. The vault door has slots that fit over two protruding U-bolts. Pad locks through the U-bolts secure the door to the frame. (b) Close-up of the vault with the door open. There is a concrete pad inside the vault for the sensor and digitizer. 


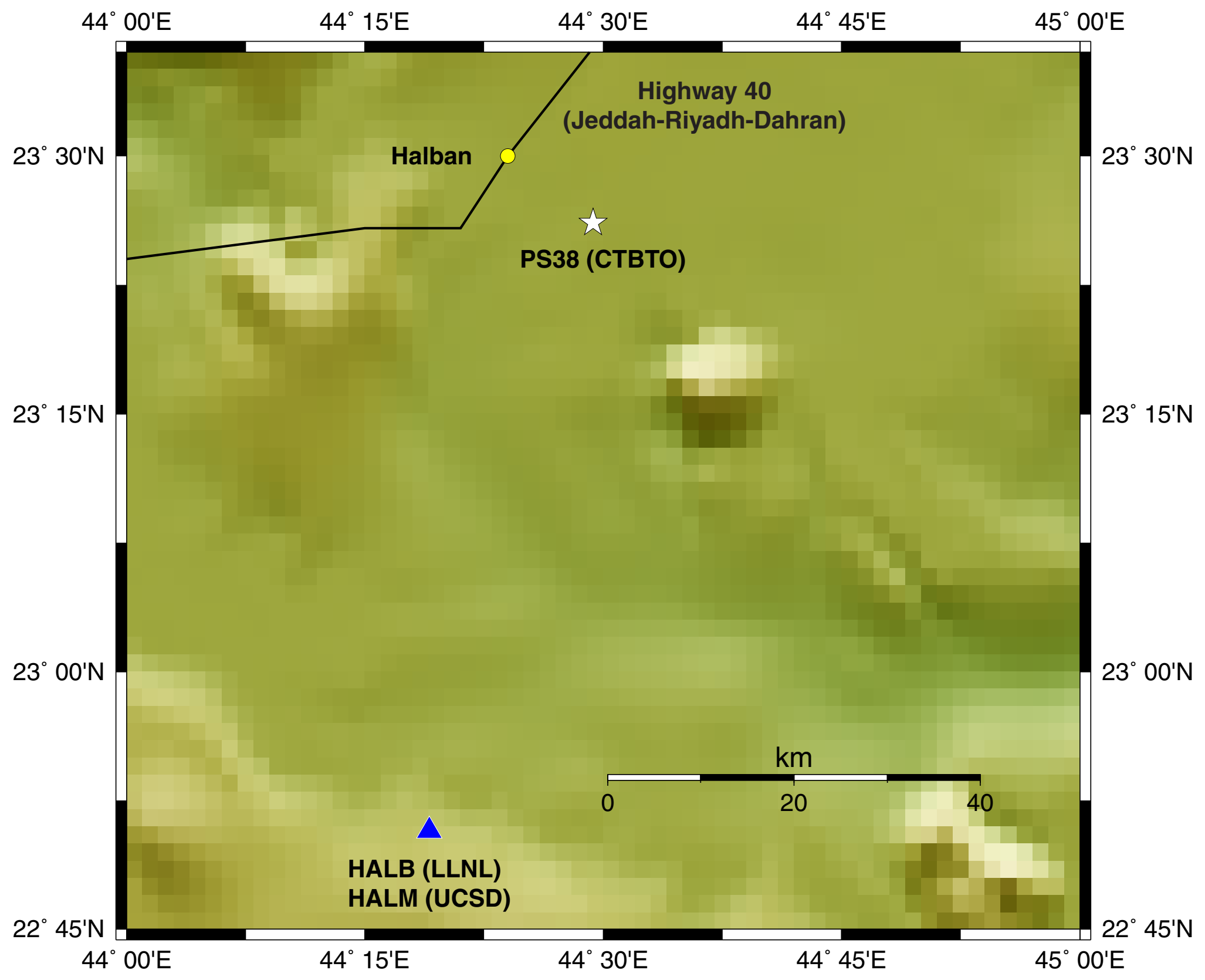

PS38 - CTBTO/IMS primary seismic array, location of site survey by CTBTO and KACST HALB - LLNL and UCSD broadband station (HALM) location

Figure 3. Locations of seismic station deployments, past, present and future, near the town of Halban in central Saudi Arabia. 


\section{Appendix - Directions to the site}

Scanned images from maps follow this pictoral guide to the site.

The town of Halban is approxiamtely $300 \mathrm{~km}$ west of Riyadh. The HALB/HALM site is about 75-80 km south-southwest of the town of Halban. The way to the site starts from Highway 40, the main east-west highway connecting Riyadh with Mekkah and Jeddah. Take the Halban (South) exit and proceed south:

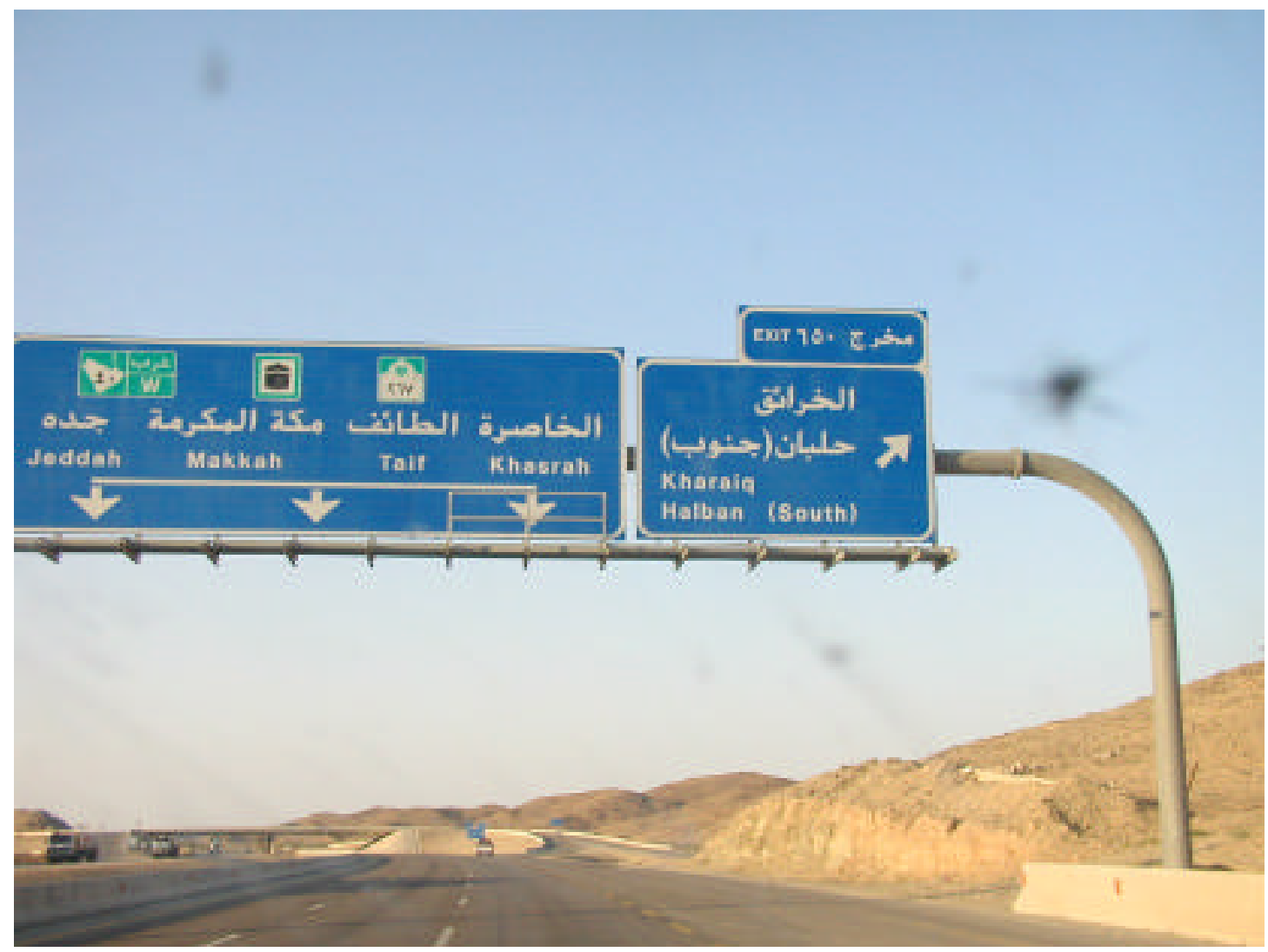

Take the overpass over the highway to the south. Proceed south and take the dirt road on the west side (right) of the road. This is a well-maintained graded dirt road capabale of $70 \mathrm{~km} / \mathrm{hr}$. Proceed on this road, past the asphalt piles on the left-hand side of the road. 
The road makes its' way across a flat desert plain, broken up by low rises between large open basins, like this one:

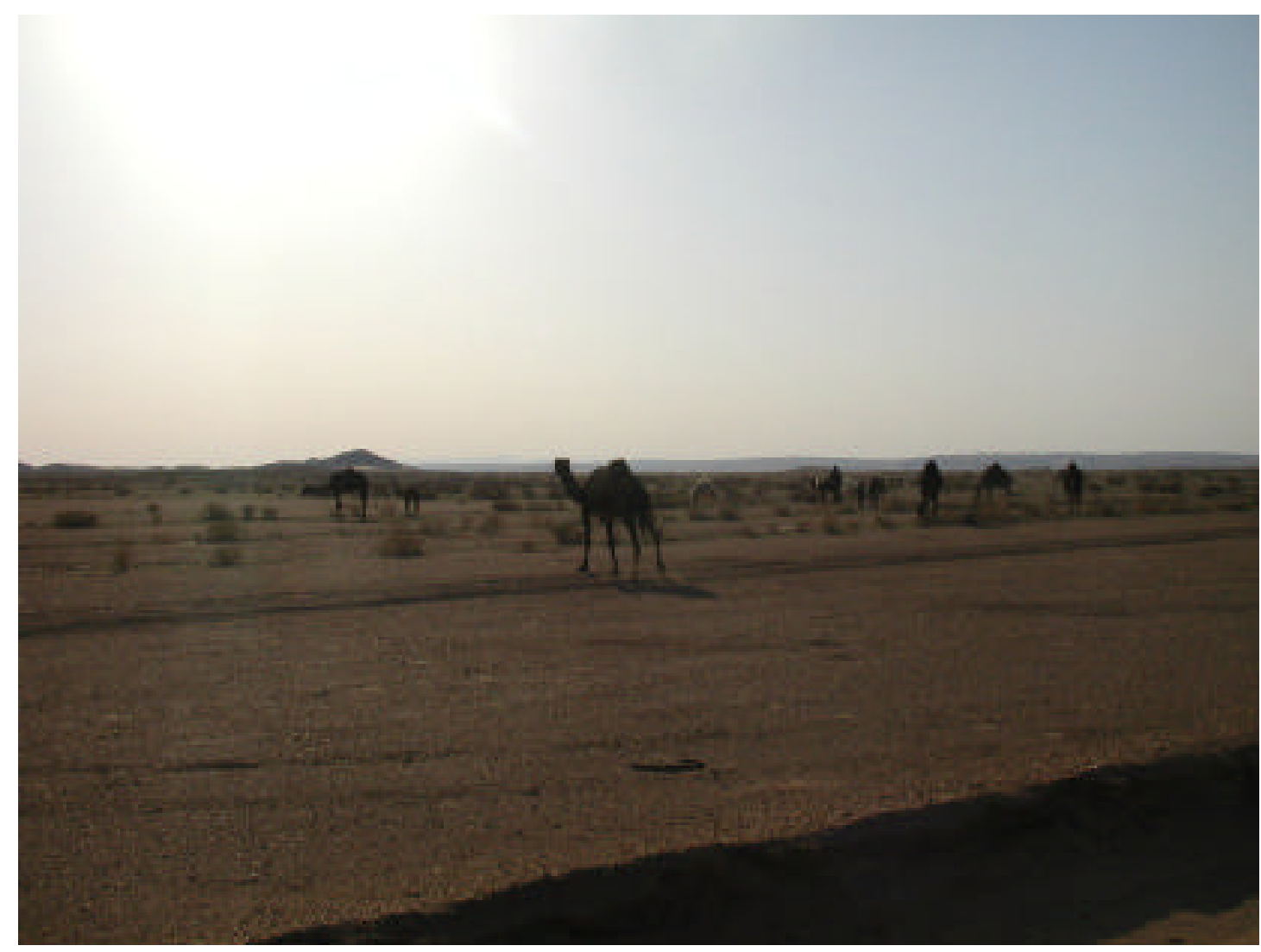

Along the way you will see camels, goats and bedouin camps. 
After climbing a slight hill, you'll come to another wide open basin. From this point you will see two prominent features - rock formations in a flat basin. The feature on the left is a steep weathered granite butte, the other (on the right) is a Sphinx-like butte, facing west. Take the road to the left of the leftmost (granite butte) feature. There's an arrow on the left-side of the butte pointing the way.

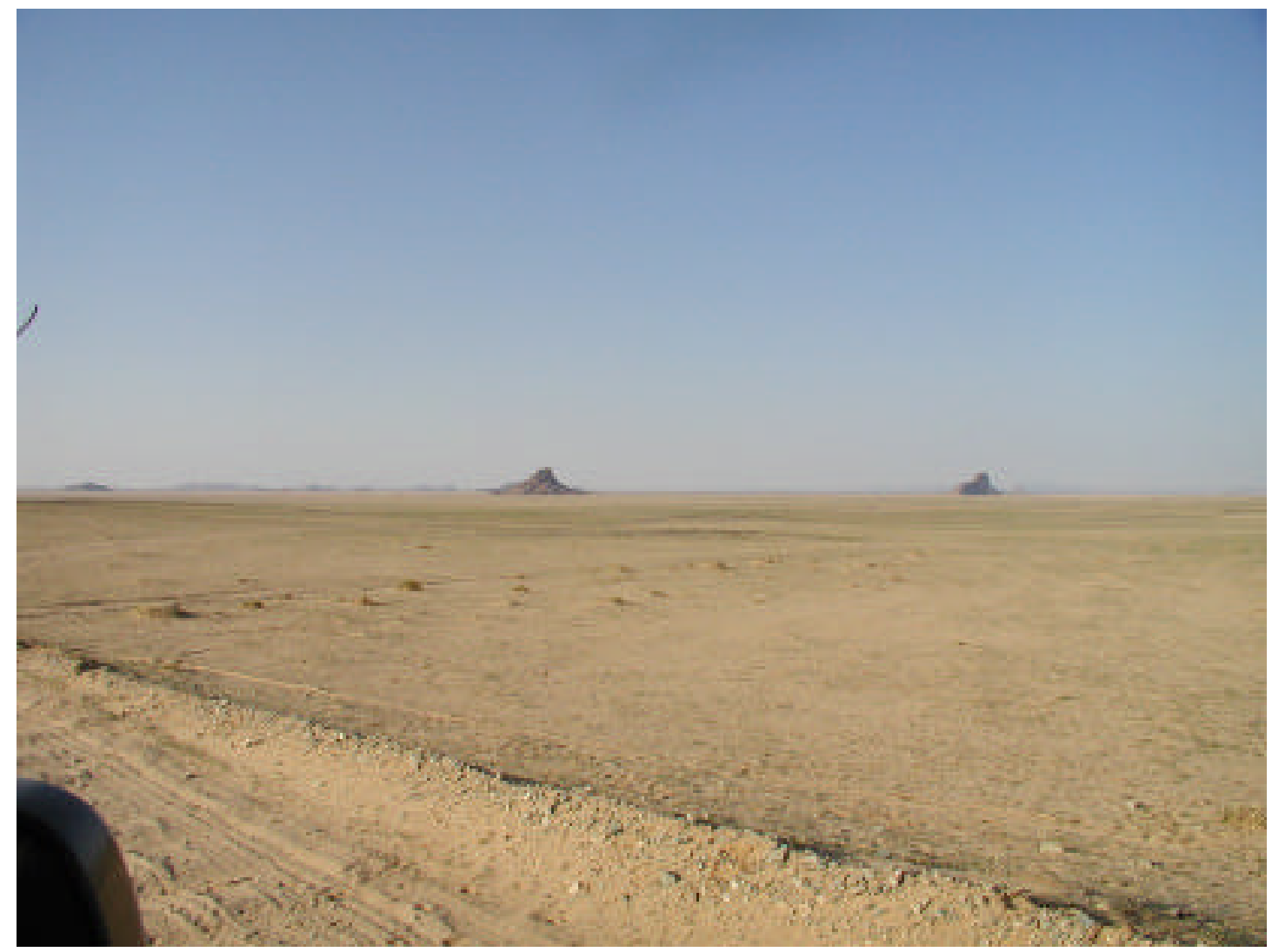


At about $76 \mathrm{~km}$ from the highway, prepare to turn left across the desert plain. The picture below shows the view to the left of the road. The site lies behind the two-peaked hill in the foreground.

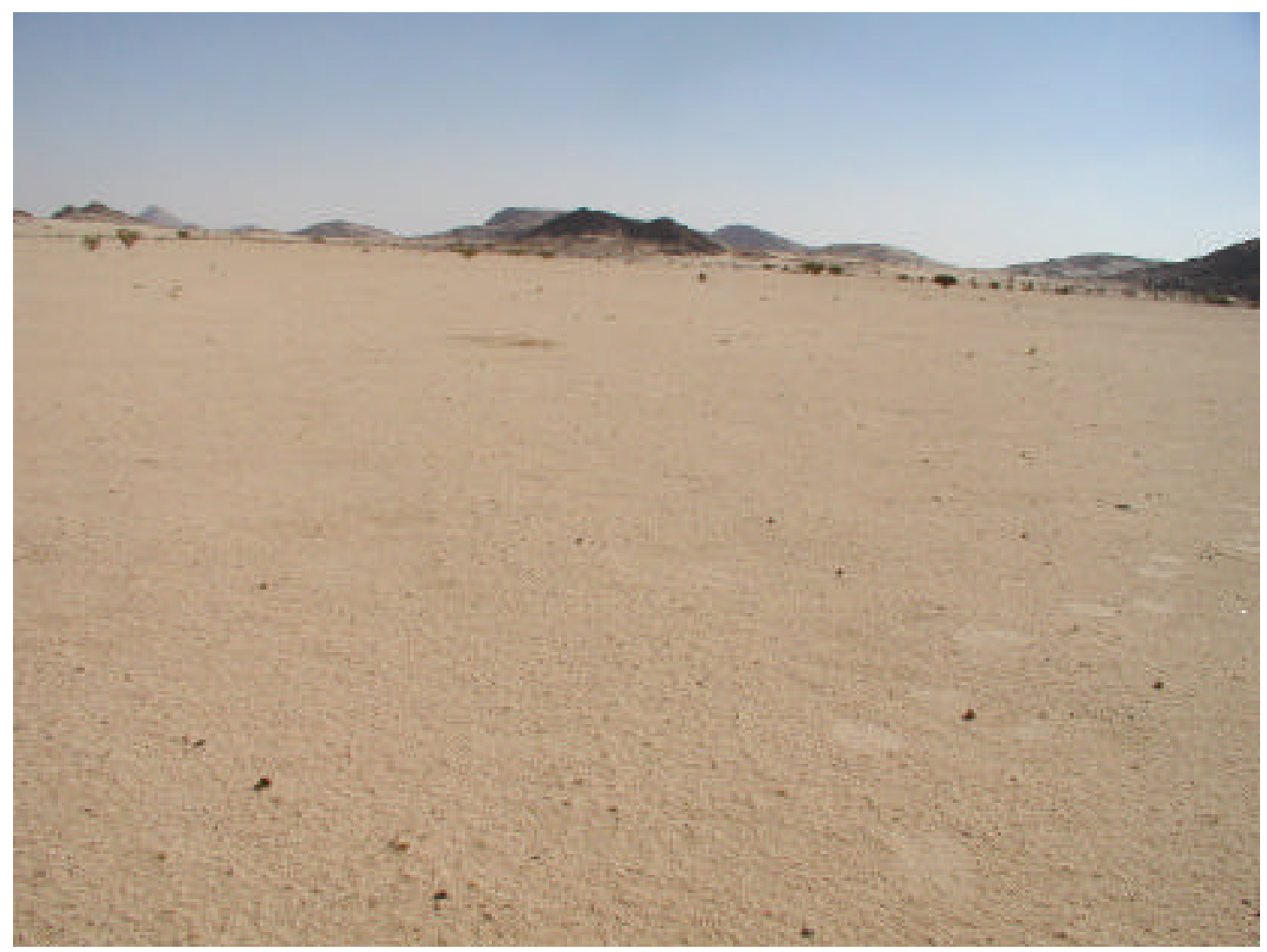

